\title{
France in Mali: Towards a new Africa strategy?
}

Tony Chafer, University of Portsmouth

\begin{abstract}
This article addresses the question whether the French military intervention in Mali in 2013 (Operation Serval) and the follow-up Operation Barkhane are evidence of a new French military strategy in Africa. The first part briefly sets out the chronology of events that led to the French intervention. The decision-making process in Paris that led to the decision to intervene and the sequence of events following the intervention is then examined, in order to show that this raised important questions about the viability of the key principles - partnership, 'Africanization' and 'Europeanization' - that informed and underpinned France's Africa policy from the late 1990s. It is argued that Operation Serval and the follow-on operation, Barkhane, need to be understood, first, in the context of the importance attached to Africa as a privileged arena for the projection of French power overseas. Second, they must be understood in the geopolitical context of the neo-liberal post-Cold War international order, within which France, as a major western power and permanent member of the UNSC, feels it has a responsibility to undertake certain actions. Third, they should also be understood against the background of the failure to reform the institutional architecture of Africa policy-making, in particular the roles of the Ministry of Defence and the 'Africa cell' at the Elysée Palace, which have traditionally played a pivotal role in Africa policy. Finally, the article argues that a new Africa strategy did emerge under President Hollande, albeit in an unplanned and incremental manner, but that the resulting policy is some distance from representing a renovated, or 'normalized', Africa policy based on a new partnership with Africa.
\end{abstract}




\section{Résumé}

Cet article traite de la question de savoir si l'intervention militaire française au Mali en 2013 (Opération Serval) et l'opération qui l'a suivie (Opération Barkhane) sont le produit d'une nouvelle stratégie militaire française en Afrique. La première partie présente brièvement la chronologie des événements qui ont mené à l'intervention française. Dans un deuxième temps le processus de décision qui a abouti à la décision d'intervenir et les évènements qui en découlent sont analysés, afin de montrer qu'ils soulèvent d'importantes questions sur la viabilité de certains principes - 'l'africanisation', 'l'européanisation', le partenariat - qui ont été à la base de la politique africaine de la France depuis la fin des années 1990. Cet article soutient que l'opération Serval et sa suite, l'opération Barkhane, doivent être comprises, d'abord, dans un contexte où l'importance que la France attache à l'Afrique comme arène privilégiée pour son rayonnement outre-mer demeure fondamentale. Deuxièmement, elles doivent être comprises dans le contexte géopolitique du nouvel ordre néo-libéral international de l'après guerre froide, au sein duquel la France, comme puissance occidentale majeure et membre permanent du Conseil de Securité de l'ONU, pense que la responsabilité lui incombe d'entreprendre certaines actions. Troisièmement, elles doivent être comprises comme résultant en partie des échecs successifs à reformer l'architecture institutionnelle de la prise de décision - en particulier le rôle du ministère de la défense et le rôle fondamental joué par la cellule africaine de l'Elysée - dans la mise en place de la politique africaine de la France. Cet article conclu que si une nouvelle politique africaine a bien émergé sous la présidence de Françoise Hollande, elle est vant tout le résultat d'une série de décisions éparses plutôt que celui d'une stratégie clairement énoncée. Cette nouvelle politique 
est loin d'être 'normalisée', car elle ne repose toujours pas sur une vision nouvelle de ce qu'un partenariat avec l'Afrique pourrait être.

\section{Keywords}

France

Africa policy

Mali

peace

peacekeeping

security

military policy

In early January 2013 President Hollande had to make a decision whether to give orders for a French military intervention in Mali. Only two months earlier he had promised that France would not put French troops on the ground in Mali. His government had been working for several months to obtain United Nations authorization for an African force to be deployed to Mali. This was agreed in December 2012 but at the same time it was announced that the African force would not be ready to deploy before September 2013. In January, rebels from the north moved south, to Konna, which is only some 700km north of Bamako. Hollande and his advisers feared that Islamist groups and the Malian military were preparing to set up a new Republic of Mali, where drug trafficking and religious extremism could flourish. So, despite his earlier promise, he decided to dispatch a French intervention force to Mali. The purpose of this article is to explore 
what we can learn from this intervention about France's Africa strategy under President Hollande.

A substantial academic literature already exists on France's 2013 intervention in Mali. The intervention has been analysed from a variety of perspectives. For example, Isaline Bergamaschi and Mahamadou Diawara (2014) argue that, while the intervention was not an oldstyle French unilateral military intervention, it was nonetheless a product of France's 'neocolonial' presence in the region. Hélène Quénot-Suarez and Aline Leboeuf (2014) focus on the institutional constraints that have made it so difficult for successive French presidents, including President Hollande, to follow through on their promise to break away from the neocolonial practices of la Françafrique. ${ }^{1}$ Setting the intervention in a wider international context, Bruno Charbonneau and Jonathan Sears (2014) analyse the Mali intervention in the context of the 'liberal peace', arguing that there is a fundamental inconsistency between the 'liberal peace' ideological form and the governance requirements it imposes, while Gorm Rye Olsen (2014) argues that, where possible, western powers prefer to provide security 'by proxy' in Africa. By this he means that African troops do the actual fighting and peacekeeping on the ground while western powers basically pay the costs, the logistics and the training of local African troops. In his view, the fact that France decided to intervene in Mali with its own troops in early 2013 underlines just how serious a threat the establishment of the radical Islamist regime in northern Mali was considered to be. Others meanwhile have focused on the Malian domestic elements of the crisis. Sergei Boeke and Antonin Tisseron (2014) warned against the temptation to treat the jihadists as a homogeneous group with common goals and modi operandi, instead highlighting the multiple fractures within the myriad, smaller factions that must be addressed if stability is to be restored to Mali. Roland Marchal (2012), in an article published before the intervention, 
analysed the historical roots of Mali's political crisis and then, in a subsequent article (2013), argued that the military intervention was unlikely to address the deep-seated political problems in the country, which went well beyond security concerns about jihadist, Islamist or criminal movements in the Sahel. Finally, Isaline Bergamaschi (2014) has explored the role of the international community in consolidating a Malian regime that grew increasingly discredited, so that aid donors - voluntarily or otherwise - ultimately contributed to creating the pre-crisis context of fragility that led to the intervention.

A key question not addressed in this literature is whether France's intervention in Mali in 2013 can be seen as evidence of the renewal of Africa policy, underpinned by a redefined strategy that lays the basis for the emergence of a new type of partnership with Africa. ${ }^{2}$ Prior to the election, the Socialist Party's Africa specialist, Thomas Mélonio, published a pamphlet promising inter alia a renewed emphasis on human rights and democracy, a reduction in France's permanent military presence and a 'modern' partnership with Africa based on transparency and greater involvement of civil society (2011). François Hollande's election manifesto made 60 commitments, the 58th of which promised: 'Je romprai avec la Françafrique en proposant une relation fondée sur l'égalité, la confiance et la solidarité. Je relancerai la Francophonie'. However, during his election campaign, François Hollande barely mentioned Africa policy, made no concrete promises and did not visit the continent. Thus, on his election to the presidency in May 2012 he held a number of ideas about what Africa policy should involve - non-interference in African affairs, an end to the practices of Françafrique and a refusal to deal with African leaders who did not embrace the principles of democracy and good governance - but he had no defined Africa strategy or policy. His first major pronouncements on Africa policy after the 
election largely reiterated the ideas laid out in Mélonio's pamphlet. On 27 August 2012 in his address to France's 163 ambassadors, he stated:

Avec l'Afrique, je veux établir une nouvelle donne. La France maintiendra ses engagements vis-à-vis de ce continent plein de promesses. Toutes les puissances du monde y sont, essayent de développer leur influence et les Africains eux-mêmes ne souhaitent pas que la France se désengage. Mais notre politique doit être différente du passé. Elle doit être fondée sur la transparence dans nos relations commerciales et économiques. Elle doit être fondée sur la vigilance dans l'application des règles démocratiques et le respect aussi des choix souverains. (Wal-Fadjri, Dakar, 29 August 2012)

Then, on his first visit to Africa, two months later, President Hollande made a speech in front of the Senegalese National Assembly that gave some further pointers as to what his new approach to Africa would mean. Five years earlier, his predecessor Nicolas Sarkozy's speech in Dakar had drawn widespread criticism throughout francophone Africa for its paternalistic tone and his assertion that Africa had failed to 'enter into history' (2007). In his own 'Dakar speech', President Hollande clearly indicated his intention to break with the condescending tone and policy incoherences of the Sarkozy era. Renewing his promise to inaugurate a new era in Franco-African relations, he said: 'Le temps de la Françafrique est révolu. Il y a la France et il y a l'Afrique. Il y a le partenariat avec des relations fondées sur le respect, la clarté et la solidarité' (Le Monde, 14 October 2012). 
What is striking about these pronouncements is the lack of clarity about what this new approach to Africa policy would actually mean in practice: beyond the rejection of Françafrique there was no attempt to outline a new strategy that might form the basis for a coherent new Africa policy. Indeed, before his election as president, Nicolas Sarkozy, in a speech in Benin in 2006, had similarly stressed the need for a new partnership with Africa, saying that Franco-African ties should 'not merely depend on the quality of the personal relations between heads of state' but should engage Africans 'as equal, responsible partners', supporting their efforts to build democracy and respect individual freedoms (Sarkozy 2006). This theme of a new partnership with Africa, as outlined by President Hollande, was redolent of that enunciated by Sarkozy six years earlier. However, it was not clear whether this proposed new partnership was rooted in a viable, concrete alternative Africa strategy. This is the question that will be addressed in the rest of this article through the prism of France's 2013-2014 military intervention in Mali and its successor, Operation Barkhane.

The first part will briefly set out the chronology of events that led to the French intervention. The second part will then examine the decision-making process in Paris that led to the decision to intervene and the sequence of events following the intervention, in order to show that this raised important questions about the viability of the key principles - partnership, 'Africanization' and 'Europeanization' - that had informed and underpinned France's Africa policy since the late 1990s. Brief mention will also be made in this section of the intervention in the Central African Republic (CAR in late 2013, as it raises similar questions to the Mali intervention about French policy. In the third part it will be shown that France's intervention in Mali and the follow-on operation, Barkhane, need to be understood, first, in the context of the continuing importance attached to Africa as a privileged arena for the projection of French power 
overseas. Whatever else the various actors involved in Africa policy disagree on, all are agreed that the French presence in Africa is a, if not the, cornerstone of France's claim to a global role in the twenty-first century. Second, these military operations must be understood in the geopolitical context of the neo-liberal post-Cold War international order, within which France, as a major western power and permanent member of the United Nations Security Council (UNSC), feels it has a responsibility to undertake certain actions. Third, after Hollande's repeated promises not to put 'boots on the ground' in Mali and CAR, they should also be understood against the background of the failure to reform the institutional architecture of Africa policymaking, in particular the roles of the Ministry of Defence and the 'Africa cell' at the Elysée Palace, which have traditionally played a pivotal role in Africa policy. As a consequence of these constraints, it will be argued that a new Africa policy did emerge under President Hollande, albeit in an unplanned and incremental manner, but that the resulting policy is some distance from representing a renovated, or 'normalized', Africa policy based on a new partnership with Africa. Rather, it will be suggested that a central focus of the Hollande presidency, especially since the Mali intervention in 2013, has been to (re)legitimize the French military presence south of the Sahara. To be sure, this is not an entirely new concern. Following widespread international criticism of France's role in the Rwandan genocide and its aftermath, there was a need to establish a new basis and justification for France's military role in Africa (Utley 2005). This was what lay behind the moves towards 'Africanization' and 'Europeanization' of policy from the late 1990s. However, the growing problem of implementing the twin principles of 'Africanization' and 'Europeanization' has made it necessary to establish a new legitimacy for French Africa policy south of the Sahara. This became more urgent under President Hollande, partly because of the ongoing international concerns about the legitimacy of external interventions following the 
recent experiences in Iraq, Afghanistan and Libya, but also, importantly, because the interventions in Mali and CAR so clearly contravened his previous promises not to intervene.

\section{From crisis to intervention}

In order to understand the origins of the Malian crisis, it is necessary to go beyond the media's focus on the 'Islamist threat' in the Sahel. The crisis unfolded in three stages. The Tuareg have been leading revolts against the central government in Bamako since Mali's independence in 1960. At independence, the Tuareg were disappointed that the French did not create a separate Sahara territory for them where, as light-skinned Africans, they would not be ruled by blacks. Following independence there were ongoing disputes over access to resources and land distribution in the north of the country and Tuareg leaders consistently demanded development of the north and the decentralization of political power. The refusal, or inability, of the Bamako government to respond effectively to these demands led the Mouvement National pour la Libération de l'Azawad (MNLA) to demand regional autonomy and, in 2012, the organization of a referendum for the independence of Azawad (the northern part of Mali). The second stage of the crisis was the military coup led by Captain Sanogo in March 2012. During 2011 the Malian army had suffered a number of defeats at the hands of the Tuareg, resulting in a significant number of casualties. Many army officers held the government, led by President Amadou Toumani Touré (ATT), responsible for these defeats, because of its failure over many years to provide adequate equipment and resources for the troops fighting in the north. On 21 March, rebel officers took control of the state television service, arrested a number of politicians from the old regime, announced the dissolution of the government and suspended the Constitution. The third stage of the crisis unfurled in the aftermath of the coup, when the MNLA took 
advantage of the resulting political vacuum in Bamako to conquer the north of the country in alliance with Ansar Dine and Al-Qaeda in the Islamic Maghreb (AQIM). Initially, the MNLA took control of Kidal, Gao and Timbuktu, but rivalries between the rebel groups meant that the MNLA was quickly marginalized, as Ansar Dine and AQIM, with superior manpower and military equipment, much of it emanating from Libya following the fall of the Gaddafi regime, wrested control of Timbuktu, then Gao, from the MNLA. Another Islamist group, the Mouvement pour l'Unicité et le Jihad en Afrique de l'Ouest (MUJAO) took control of the town of Menaka in the east.

The complex, and constantly shifting, cleavages between these groups need not concern us in detail here (for more on this, see Marchal 2012: 3-5), other than to say that they render the search for a political solution to the crisis highly problematic. After the coup, clashes broke out between supporters of the coup and those opposed to it. The former believed the coup offered an opportunity to end ATT's regime and establish a 'genuine' democracy in Mali (a general election was due the following month), while the latter, comprising much of Bamako's political class that had benefited from the ATT regime, condemned the coup and demanded an immediate return to constitutional rule and the restoration of the territorial integrity of the nation, a position supported by the country's international partners, including the Economic Community of West African States (ECOWAS).

As a result of the occupation of the north of the country and pressure from ECOWAS, the coup leaders agreed to transfer power to an interim, civilian government on 6 April 2012, although the coup leader, Captain Sanogo, continued to exert considerable influence over it. However, by late 2012 it had not been possible to reach agreement on any of the central issues facing the country: how to regain control of the north, arrangements for the political transition or 
the organization of elections. The army was unable to regain control of the north on its own, yet the ex-junta refused to countenance any foreign support. Just as seriously, negotiations between the protagonists in the conflict could not start, as the coup had left the transitional government unable to act. The mediation efforts of external parties, such as ECOWAS, also failed. Then, on 20 December 2012, the UNSC adopted Resolution 2085, which approved the deployment of an African military force in Mali. However, the simultaneous announcement that African troops would not be ready to deploy before September 2013 encouraged the rebels to take action as soon as possible. Ansar Dine broke the ceasefire and attacked Konna on 9 January, thus crossing the line between the areas under their control and the southern zone controlled by the government, prompting concerns that the rebels planned to attack the strategically important airport at Sevaré and from there advance on Bamako.

By early January French intelligence services claimed to have detected intense communication between armed groups in the north of the country which were preparing an attack (Mathias 2014: 29). They feared that terrorists had infiltrated the capital and were negotiating a potential alliance with the putschists and/or other socio-political actors close to the Coalition of Patriotic Organisations of Mali - the pro-putsch coalition formed in March. Thus French policymakers in Paris believed that 'black flags were at the doors of Bamako' and that Mali was on the verge of becoming a fundamentalist Islamist state where drug trafficking and religious extremism could flourish. African regional heads of government, notably Mahamadou Issoufou and Macky Sall, who were fearful of the impact of an Islamist takeover of the country, also pressed the government to intervene (Charbonneau 2014: 622; Glaser 2014: 100; International Crisis Group [ICG] 2012). This vision of things may not have been based on an accurate assessment of Islamist intentions or of the potential resistance by ordinary citizens. Nevertheless, it fuelled the 
widespread belief that something needed to be done to prevent the Sahel from becoming a safe haven for terrorists. It was this that prompted the French president to launch Operation Serval on 11 January 2013.

\section{The French decision to intervene and its aftermath}

In his book Les Guerres africaines de François Hollande, Gregor Mathias (2014: 30-33) provides an interesting insight into how the president came to make the decision to launch Operation Serval. He points out that, by January, all the other possible solutions had failed: the EU had decided in 2012 not to deploy a Common Security and Defence Policy (CSDP) military mission, the UN was not ready to send troops and African leaders were still negotiating arrangements for deploying an African force. Also, Hollande's Africa advisers were silent and the Ministry of Foreign Affairs appeared more preoccupied by developments in Syria. Against this background his private army chief of staff, General Puga, warned the president that armed pick-up trucks were ready to advance on Bamako and gave him an hour in which to make a decision about an intervention. Puga also suggested that, in order to make the intervention legal, the president should obtain from Mali's interim president a letter requesting a French intervention. This was obtained, although it only requested air and intelligence support. According to Vincent Jauvert and Sarah Halifa-Legrand (2013), the French authorities then revised the letter, so that it made explicit reference to an airborne military intervention, and returned it to the interim president for signature. ECOWAS, whose president was the Francophile Ivoirian leader, Alassane Ouattara, also gave its support (Glaser 2014: 61). Having received reassurances from General Puga about the feasibility of the operation, the president launched Operation Serval. 
We do not have to verify all the details of this story, such as the picture of General Puga pacing up and down outside the president's office waiting for his decision, to see its significance for Hollande's promise of a new Africa policy based on multilateralism and a new partnership with Africa. The EU, UN and African regional bodies (the African Union [AU] and ECOWAS) had either decided against a military operation or were not in a position to take the initiative. As for the new partnership, this apparently involved the French authorities themselves drafting the letter that rendered the operation legal. If 'Africanization' was supposed to mean ensuring that any military intervention has been requested by the government of that country, has the prior approval of the relevant African regional body and involves African forces taking the lead role, then the policy of Africanization is some way from meeting this objective. The operation, which involved the deployment of about 4000 French troops supported by 2000 Chadians, officially took place in coordination with the Malian army. However, the latter was in no state to be able to play any significant role in the operation. Shortly after the launch of the operation, an Africanled International Support Mission to Mali (AFISMA) was set up, with troops from Nigeria, Benin, Burkina Faso, Senegal and Togo, to operate alongside the French and Chadian forces of Operation Serval, before being replaced on 1 July by the United Nations Multidimensional Integrated Stabilisation Mission in Mali (MINUSMA). The Mission was established by Security Council resolution 2100 of 25 April 2013, under the terms of which it would:

support the political process and carry out a number of security-related stabilisation tasks, with a focus on major population centres and lines of communication, protecting civilians, human rights monitoring, the creation of conditions for the provision of humanitarian assistance and the return of displaced persons, the extension of State 
authority and the preparation of free, inclusive and peaceful elections. (United Nations 2013)

French forces continued to operate independently in support of the UN Mission but were not integrated into it.

The foregoing analysis might appear to suggest that France intervened reluctantly and only when other actors had demonstrated their inability or unwillingness to intervene in the crisis. Yet it is striking, if France was so reluctant to intervene, that it was able to respond so rapidly and deploy troops so quickly. Clearly, the Ministry of Defence already had a well prepared plan for deployment, which went well beyond the usual contingency planning (Mathias 2014: 33-34; Chivvis 2016). The operation was a military success, insofar as it very quickly chased the rebels from cities and later from the mountains of Adrar. The military threat did not go away, however, and on 19 September President Hollande declared that French forces would 'stay as long as the threat exists' (Ministère de la Défense 2013). Well-armed rebels, often supported by experienced fighters from Gaddafi's Libya, were continuing to mount sporadic attacks across the north and receiving supplies from southern Libya (Africa Confidential, 9 January 2015). Northern Mali is larger than metropolitan France: combating fighters, who are highly mobile, know the country well and move in and out of Mali, was therefore an ongoing problem. It was also one that the Malian army was still not in a fit state to address, despite efforts to retrain the Malian army prior to the military coup by the US and, since 2013, by the EU Training Mission (EUTM). The failed attack on Kidal in May 2014 is evidence of this. 50 government soldiers died in the attack, which led to protests outside the French and UN missions in Bamako and accusations from the prime 
minister of Mali that the French and UN forces had failed to guarantee his security on a visit to the northern town (Africa Confidential, 30 May 2014).

Having initially been welcomed by most Malians, Operation Serval was facing growing problems by mid-2014. In late 2013 the French government was criticized for paying ransoms to AQIM for French hostages (Africa Confidential, 1 November 2013). It was also increasingly not seen as a neutral broker between the different parties in the Malian conflict. Largely thanks to its historical support for the Tuareg, many Malians, particularly but not only from the governing elites in Bamako, believed that France continued to harbour sympathies for the Tuareg and that it had secretly agreed to hand Kidal and some other northern towns, which the Malian army was not allowed to enter, over to the MNLA (Africa Confidential, 30 May 2014). This provoked anger in Bamako and rendered the implementation of a policy of 'partnership' increasingly problematic; in a situation of conflict, partnering with one party to the conflict would inevitably be seen by some on the opposing side as taking a stand against them (Harmon 2015: 236).

The transformation of Operation Serval on 1 August 2014 into the much larger regional operation, Barkhane, addressed this problem by recasting French military actions across the region as a wide-ranging counter-terrorism operation targeting Islamist extremists with a mandate to operate across borders (BBC 2014; Harmon 2015: 237). Operation Barkhane is a merger of two French military operations: Operation Epervier (launched in Chad in 1986) and Operation Serval (which came to an end on 1 August). It retains the troops based in Chad and Mali from these operations, but its theatre of operations now stretches across the whole of the francophone Sahel/Sahara region and spans five countries (Mauritania, Mali, Burkina Faso, Niger and Chad - referred to on the French Ministry of Defence website as the 'G5 Sahel'). It comprised in 20153000 men, 200 supply vehicles, 200 armoured carriers, six fighter planes, 
twenty helicopters, seven transport planes and four drones. Its aim is twofold: to support the armed forces of the participating countries in their interventions against armed terrorist groups across the Sahel and to help prevent the re-establishment of terrorist sanctuaries in the region. In keeping with Hollande's promise, the policy discourse regarding Barkhane is very much one of partnership with, and support for, African forces. The reality is, however, that the capacity of the armed forces of these countries (with the exception of Chad) to intervene outside their national territory is limited. Moreover, the military in countries like Niger, Mauritania and Chad often prefers to work with the competent and reliable French military, rather than an untested multinational African army whose fighting capacity is uncertain and political commitments may lie elsewhere. Once again, the problems confronting a policy of 'Africanization' are exposed: if it was supposed to mean building African peacekeeping capacity so that Africans are able to take responsibility for peace and security on the continent, thus reducing the need for direct intervention by French troops, then Operation Barkhane demonstrates the limits of this policy.

There is not the space here to go into detail about France's other military intervention in Africa since President Hollande's election in 2012. However, it is worth mentioning briefly Operation Sangaris, which was launched in the CAR on 5 December 2013, as it raises similar questions about French policy. As in Mali, Hollande originally said that there would be no French intervention in CAR and indeed turned down a request in late 2012 from the then president, François Bozizé, to intervene in order to prevent a northern Muslim rebel movement, Séléka, from taking over the country. Subsequently, Séléka ousted Bozizé from power and Michel Djotodia became the first Muslim president of the country. In October 2013, fighting broke out between Séléka and largely Christian self-defence militias, called anti-balakas, which the government was unable to control. Concerned about the growing inter-communal violence, the 
French government pressed for a UNSC resolution that would authorize the deployment of an African-led peacekeeping force. Finally, the South African government asked the French to intervene in October 2013 (Institute for Security Studies 2013).

Resolution 2127 was adopted on 5 December 2013 and provided for an African-led International Support Mission to the Central African Republic (MISCA), to restore order and end religious tensions in the country. It also authorized French forces already in the CAR to take all necessary measures to support MISCA in the discharge of its mandate. Once again, the problem of 'Africanizing' responsibility for peace and security on the continent was clear. African forces from the Central African Economic and Monetary Community (CEMAC), which were deployed in 2002, and from the Economic Community of Central African States (ECCAS), which were deployed in 2008, had been unable to stabilize the situation (Mathias 2014: 216). France, which could have intervened in 2012 as it already had troops on the ground in the country, declined to do so. The human rights situation worsened dramatically, so that an intervention to protect the population became unavoidable. Once again, thanks to its long history of involvement in the country going back to the colonial era, and its pre-positioned troops already on the ground, the international community turned to France in an effort to stabilize the situation. Only France could deploy troops immediately, doubling its troop complement in the country to 1200 in a matter of days, while the MISCA was not expected to reach its full operational capacity until September 2014 (France at the United Nations 2014). As was the case with Operation Serval, the United Kingdom and Belgium assisted with transport and Germany sent a medical transport plane but, although an EU military mission (EUFOR CAR) was established on 10 February 2014, it did not become operational until 15 June 2014 due to the reluctance of EU member states to send troops. In the end, half of the 700 troops deployed were French and most of the rest were from Georgia, 
Estonia, Latvia and Poland, which agreed to deploy troops in return for support from France in the Ukrainian crisis (Quénot-Suarez and Leboeuf 2014: 34).

Similar problems have thus faced operations Serval, Sangaris and Barkhane. First, because of the reluctance of other external powers to take the lead on peace and security, political disagreements between regional actors which prevent them taking the lead, the inadequacies of the UN and the EU's failure to agree and implement an effective military response to the crises, France has found itself in the position of playing the lead role in guaranteeing peace and security in West and Central Africa. Second, 'Africanization' of responsibility for peacekeeping on the continent has in practice proved highly problematic. Despite the fact that the RECAMP (Renforcement des Capacités Africaines de Maintien de la Paix) programme for building African peacekeeping capacity has been in place since 1998, it clearly has not succeeded in its objective of training African peacekeepers so that they are able to take over responsibility for peacekeeping on the continent.

\section{The limits of 'Europeanization'}

Alongside 'Africanization', the other key principle that was supposed to guide Hollande's approach to Africa policy can be summed up as ‘Europeanization'. For Mélonio (2011: 31-32), the Europeanization of policy would mean, first, EU member states, through the European External Action Service, sharing responsibility for the protection - and eventual evacuation - of EU citizens in Africa. Second, it would mean Europeanizing the French military presence on the continent, thereby freeing up more French troops and resources for NATO- or UN-led operations in Africa (Mélonio 2011: 33-34). Europeanization was also seen as a means of avoiding the charge of neo-colonialism, insofar as an EU military operation would not have the same direct 
association with France and would thus be seen as more politically 'neutral'. More generally, from a French point of view, Europeanization, like Africanization, is about burden-sharing: sharing the risks, and costs, of military operations in Africa with other EU member states.

Neither of these principles was entirely new. In 1997 Prime Minister Jospin introduced RECAMP, France's African peacekeeping capacity-building programme. Subsequently, President Chirac (2002-2007) made efforts to Europeanize military missions to Africa and increased emphasis on African capacity-building through closer links with the AU. His successor, President Sarkozy (2007-2012), oversaw the Europeanization of RECAMP, which was renamed EURORECAMP in 2008 and placed under the European Council. Under presidents Chirac and Sarkozy there were also three French-inspired European Security and Defence Policy (ESDP) military missions on African soil: Operation Artemis in the Democratic Republic of Congo (DRC) from June to September 2003; EUFOR, also in the DRC, from July to November 2006; and EUFOR Chad/CAR from January 2008 to March 2009. However, having been persuaded to take part in French-led military operations on the continent under the ESDP from 2003 to 2009, EU member states, notably but not only Germany, became sceptical about the value of direct EU military interventions in African crises. Either they did not attach the same strategic importance as France to security problems in Africa, or they were wary of France seeking to implicate them in 'its' African problems, or they were simply happy to leave military action to France, as it has troops in the region and is clearly ready, willing and able to intervene. Partly as a consequence of this, France's initial Europeanization strategy for its African military interventions proved short-lived, as no troops from other EU member states have been deployed in a combat role to Africa since EUFOR Chad/CAR. 
At the same time, there has been a shift in French policy towards involving the EU in its peace and security efforts in Africa. As a result, France has changed tack. It no longer seeks to Europeanize its military interventions and now privileges instead a 'division of labour' approach, with the EU in a supporting role. Indeed, the Mali intervention was an example of this, whereby France deployed troops in a combat role to fight the rebels - variously described as 'Islamists' or 'terrorists' - while the task of retraining the Malian army has been devolved to the EU (EUTM Mali) and UN forces in MINUSMA have taken on the role of peacekeeping. Barkhane continues, and effectively institutionalizes, this approach, with France deploying combat troops and special forces from various bases across the G5 Sahel countries to fight the 'terrorists' and the EU deploying two civilian CSDP missions (EUCAP Sahel Mali and EUCAP Sahel Niger), which provide assistance in training the police forces of these countries to address counterterrorism tactics and strategies. The EU additionally provides aid to Sahel countries through a variety of mechanisms, such as its Sahel Regional Action Plan 2015-2020.

\section{The drivers of French intervention}

Sub-Saharan Africa has, since the end of the colonial era, been a privileged arena for the projection of French power - 'rayonnement' - overseas (Chafer 2002: 345-46). The continuing importance of Africa in this regard was underlined by the 2013 Defence White Paper (Livre Blanc 2013: 54) and reiterated in the National Assembly's report on Operation Serval in 2014. Moreover, whereas the 2008 Defence White Paper (Livre Blanc 2008) had proposed the closure of some military bases in Africa, the 2013 White Paper reverses this decision and places France's pre-positioned troops at the heart of its new Africa strategy: 
Le Livre blanc sur la défense et la sécurité nationale de 2013 fait du Sahel une des zones d'intérêt prioritaire pour la France. Alors que la fermeture de certaines bases prépositionnées avait été envisagée en 2008, le Livre blanc de 2013 place le dispositif prépositionné au cœur du modèle d'armée et de la stratégie de prévention des crises: 'la coopération de défense et de sécurité, l'assistance opérationnelle à des armées étrangères, ainsi que notre dispositif prépositionné, constituent autant d'outils qui doivent contribuer à la cohérence de notre politique en matière de prévention'. (Assemblée Nationale 2014, original emphasis)

It is at this point that a geopolitical frame of analysis can help us. Geopolitics is essentially a multidisciplinary approach to understanding international relations (IR) with a stronger emphasis on the 'geo' - that is, the territorial and spatial dimensions - than is apparent in many traditional IR analyses. Furthermore, by focusing on 'the changing role of the State and the dynamic nature of the relationships between states at both global and regional levels' (Newman 2007: 3), it also incorporates a historical dimension. Thus, the argument presented here is that, if we are to understand how France came to intervene in Mali, we need to analyse the interplay between three dimensions - the spatial, the historical and the political.

Taking the spatial dimension first, the most significant strategic interest for France in the region is not situated in Mali, but in Niger where Areva, France's state-owned nuclear power company, extracts 30 per cent of its uranium. Ensuring the security of activities and personnel has been increasingly difficult in the past years, as illustrated by the kidnapping of five French nationals in 2010. The presence of Islamists and the prevalence of criminal activities, from drug 
running to people trafficking and kidnapping of westerners, are perceived as a security threat to Europe (European External Action Service 2011), but it is a threat that, at least until the migration crisis that started in 2014, was felt more acutely in France because of the demographic importance of African diasporas from this part of the world in mainland France (Livre Blanc 2013: 54-55). This led to the perception by French policy-makers that insecurity in the Sahel/Sahara region posed a particular threat to France, a perception that led France to take the lead on tackling security issues in the region.

The spatial, historical and political dimensions are closely linked. As already noted, subSaharan Africa has been a privileged arena for the projection of French power overseas. West and Central Africa are especially important for France in this respect because of the strong historic ties it has with the region that date back to the colonial period. These ties intensified with many of France's ex-colonies after independence. In addition to its military presence, France has maintained a dense diplomatic network, many countries belong to the Franc zone, the former French colonies have French as their official language, and the region also plays an important role in relation to France's energy security as a supplier of oil and of uranium for its nuclear electricity industry. Outside Europe it is the one area of the world where France continues to be viewed as the leading western power.

Moreover, geopolitics is not only about interests, but also about beliefs, norms and values. In this context, intervening in Mali was an opportunity for France to show that it was honouring its international obligations:

En intervenant au Mali, la France assume ses responsabilités internationales et remplit ses obligations internationales. Des intérêts 
essentiels étaient en jeu pour nous, pour l'Afrique, pour l'Europe et pour

l'ensemble de la communauté internationale et il fallait donc agir.

(Ambassade de France à Tunis 2013)

Thus, according to Foreign Minister Laurent Fabius, the intervention allowed France to demonstrate its willingness to take responsibility for dealing with global terrorism in 'its' area of influence. Moreover, in the French geopolitical imaginary, France is a medium-sized power that continues to have a global role. However, since the country is no longer a major player on a global scale in terms of population and economics, a strong belief subsists among France's governing elites that acting for stability in Africa remains a key tool to justify retaining the French permanent seat at the UN Security Council. Against this background, the Mali intervention presented French authorities with the opportunity to send a message to domestic public opinion, and indeed to the armed forces themselves, about the central role that they play in sustaining France's global role. During a speech delivered to Serval troops in Bamako in September 2013, Hollande (2013a) stated that it is thanks to its army that France enjoys its 'sovereignty, independence and $[\ldots]$ credibility'. Crucially therefore, the intervention served to underpin and strengthen beliefs concerning France's international status and role on the global stage.

Related to this, it is important to underline that there has been a significant shift in French strategic thinking between the 2008 and 2013 Defence and National Security white papers. While both white papers attached central importance to France fulfilling its international obligations, ensuring the country's independence and protecting French nationals, there was an emphasis in the 2008 white paper on European cooperation. As Nicolas Sarkozy stated in the preamble to the white paper: 'Cette stratégie porte une ambition européenne et internationale' (Livre Blanc 2008: 
10). The tone of the 2013 white paper was markedly different. In his preamble to the latter, François Hollande asserted that the three principles at the heart of French defence and security policy are protection, deterrence and intervention. In order to implement these principles, the emphasis throughout the white paper was on the autonomy of the state, both in decision-making and in the actions it undertakes (Livre Blanc 2013: 19). This was justified by reference to the changing international strategic context, in which the United States has become less willing to undertake external military interventions and expects Europe to play a greater role in ensuring its own security, and in which progress towards the adoption of a common EU security and defence policy has been slow. Against this background 'le maintien de notre autonomie stratégique, gage de liberté de décision et d'action, s’impose comme le premier principe de notre stratégie' (Livre Blanc 2013: 88). In short, there has been a return to a geopolitical discourse in French strategic thinking that emphasizes the risk of losing great power status and stresses the need to retain the autonomy and the sovereignty of the nation, a notion that is completely incompatible with the Europeanization of security policy.

\section{A new Africa strategy?}

The central plank of President Hollande's new Africa policy before his election and in the early days of his presidency was to put an end to Françafrique. However, dismantling Françafrique is not in itself a strategy. Unsurprisingly therefore, it was not long before incoherences began to manifest themselves. Shortly after Hollande's October 2012 Dakar speech, in which he promised a new partnership with Africa based on transparency, respect for democratic principles and human rights, he went to Kinshasa for the francophone summit, where he refused to shake hands in public with the host, DRC's president, Joseph Kabila, having previously described the human 
rights situation in that country as 'tout à fait inacceptable' (Le Monde, 15 October 2012). In the same month he also refused to invite President Déby of Chad to the Elysée Palace because of his government's human rights record and instead sought to forge direct links with NGOs and civil society organizations (La Lettre du Continent, 25 October 2012). However, facing a rapidly deteriorating situation in Mali and desperately in need of regional allies who could support any military action that France might take, in December Hollande invited Déby to the Elysée Palace and just one month later French troops intervened in Mali alongside 2000 Chadian troops. Traditionally a close ally of France, Chad is now one of the 'G5 Sahel' countries taking part in Operation Barkhane, despite Déby being a dictator with a long history of abuse of human rights and political violence against opponents (Styan 2013: 233-48).

The Mali intervention is evidence of a disjuncture at two levels. There is a tension between, on the one hand, a rejection of Françafrique and the discourse of a new partnership with Africa, and on the other, the reality of a partnership that remains, as before, an essentially asymmetric one, in which France takes the military lead and in which geopolitical concerns continue to trump the commitment to human rights and democracy.

A second disjuncture is evident between the continuing importance of Africa as a privileged arena for the projection of French power, which it has not been possible to reconcile with the commitment to breaking with the past. To be sure, the notion of francophone Africa as an exclusive area of French intervention was transformed under the presidencies of Chirac and Sarkozy, so that French military interventions are no longer justified by reference to its historic responsibilities and family-like obligations to many sub-Saharan African countries. Instead, the justification for intervention relates to the need to establish security and the rule of law as prerequisites for development and for the effective integration of a peaceful and prosperous 
Africa into the global economy (Charbonneau and Chafer 2014: 7). In this sense France has fallen into line with other western powers in promoting the 'liberal peace' ${ }^{3}$ in Africa. Yet France's colonial past in West and Central Africa, its continuing military presence across the continent and its history of military interventions since 1960 have rendered the implementation of this new approach problematic in practice, as the 2013 military deployment in Mali once again highlighted. The potential for incoherence exists at two levels. First, the normative, 'liberal peace' approach itself bears enormous potential for and inconsistencies within itself. Second, the legacy of France's colonial past and its continuing postcolonial presence in Africa, notably in the military sphere, presents further potential for contradictions in French strategy, insofar as it collides with the 'liberal peace' approach.

Constructing the 'liberal peace' in Mali was, as Charbonneau and Sears (2014) argue, inherently problematic, as it assumes a unity across the national territory that does not exist. The discourse of national unity has been belied throughout Mali's postcolonial history by practices of social exclusion, exploitation and entrenched injustices, notably but not exclusively vis-à-vis the north, so that any project of state (re)construction is inherently contested. Moreover, the liberal, market-oriented vision of post-authoritarian, post-Cold War Mali, with its neoliberalizing agenda, is promoted by Bamako-based 'donor-oriented, professional civil society' but not shared by the mass of the population (Bergamaschi 2014: 363). The 2013 presidential and legislative elections, which were demanded by France and other international donors but criticized by some as being premature (Bouverie 2013), were enthusiastically and uncritically hailed as evidence of democratic consolidation and a return to the pre-coup peace. Yet this enthusiasm for elections, which are a requirement of the 'liberal peace', ignored the deep-rooted domestic governance problems arising from political divisions between the north and the south 
and 'growing sociocultural divisions between urban elites and the rest of the population' (Van de Walle 2012). Holding elections, of itself, did nothing to resolve these issues.

At the same time, France's intervention in Mali was in many ways redolent of the unilateral French military interventions of the past. Indeed it was, as we have seen, General Puga, Hollande's personal Chief of Staff at the Elysée Palace, veteran of many French military interventions in Africa since 1978 and a former head of military intelligence, who recommended the intervention to President Hollande and assured him that it could be carried out successfully. This tension between constructing the 'liberal peace' and asserting France's continuing postcolonial presence and activism in the region is also evident in the various justifications for the intervention that have been offered. On 11 January 2013, Hollande announced that France would 'respond to the request of the Malian president' and send forces to its former colony to fight 'terrorist elements coming from the north'. He went on: 'Military operations will last for as long as required [...] Terrorists must know that France will always be there when it's a matter not of its fundamental interests but the right of a population [...] to live in freedom and democracy' (Smith 2013: 3). Two different discourses coexist here. First, there is the postcolonial one: 'France will always be there' to provide help within its pré carré (privileged sphere of influence). This is followed by a reference to protecting human rights and the right, consistent with the 'liberal peace', to 'live in freedom and democracy'. A few months later, in May 2013, Army Chief of Staff Admiral Guillaud testified in front of the French National Assembly defence commission, that:

Les objectifs fixés par le Président de la République lors des conseils restreints de janvier étaient parfaitement clairs: stopper l'offensive vers 
Bamako et ainsi préserver l'existence d'un État malien; détruire [...] et désorganiser la nébuleuse terroriste; aider au rétablissement de l'intégrité et l'unité territoriales du Mali; enfin, rechercher les otages, les nôtres en particulier'. (Assemblée nationale 2013)

Here again, different discourses coexist. First, there is the reference to preserving the Malian state, as this is presumably seen as the only possible harbinger of freedom and democracy. Two further justifications for the intervention are then offered: to combat terrorism and protect French interests by looking for hostages: 'ours in particular'.

Yet another justification was put forward by the president himself in a speech in Bamako on 2 February 2013, when, in contradiction to the commitment to normalize Franco-African relations and establish a new partnership with Africa, he explicitly justified Operation Serval by reference to the two countries' shared colonial past:

Moi, je n’oublie pas que, lorsque la France a été elle-même attaquée, lorsqu'elle cherchait des soutiens, des alliés, lorsqu'elle était menacée pour son unité territoriale, qui est venu alors? C'est l'Afrique, c'est le Mali. Merci au Mali. Nous payons aujourd'hui notre dette à votre égard. (Hollande 2013b)

As Bergamaschi and Diawara (2014: 146) point out, the intervention is in this way made more acceptable by presenting it within 'a framework of gift and counter-gift between states and peoples'. Thus, in explaining and justifying the Malian intervention President Hollande has sought to incorporate a range of alternative, though sometimes contradictory, policy rationales. 
It should be pointed out at this stage that these two dimensions - the Franco-African special relationship and the 'liberal peace' - are not discrete, but are in a dynamic and constantly changing relationship. Sometimes they overlap, as seen here in the discourse used to justify the Mali intervention. They may also converge in driving the interventions themselves, as FrancoAfrican relations have become integrated into global governance and both French and some African elites are integral parts of the liberal peace/global governance structures. At other times, however, these two dimensions may find themselves in contradiction, as for example when France allied itself with Deby's Chad to intervene in Mali in the name of protecting human rights and good governance.

Finally, in order to understand how the Mali intervention came about, it is important to remember that the fragmented institutional framework and policy-making community, each with their own agendas and institutional culture, that have governed French Africa policy since the end of the Cold War, have not been overhauled by President Hollande (Quénot-Suarez and Leboeuf 2014: 8). Under the Fifth Republic the president and his 'Africa cell' at the Elysée Palace have traditionally taken the lead on Africa policy. The Ministry of Defence, as Jean-Louis Triaud (Mathias 2014: 13-14) has shown, also plays a key role and tends to have greater influence than the Ministry of Foreign Affairs, largely because the president traditionally seeks advice from topranking military figures (chiefs of staff and military intelligence chiefs) on African issues. Officially, after his election Hollande abolished the 'Africa cell' as part of his effort to put an end to Françafrique and appointed as his Africa adviser Hélène Le Gal, a career diplomat whose previous experience was of East Africa, far removed from the networks of Françafrique, with Thomas Mélonio, who previously worked for the Agence Française de Développement before taking charge of Africa policy at the Socialist Party, as her deputy. However, when the Mali crisis 
came to a head, General Puga was the only person to put forward a plan of action to address the situation. His access to military information and intelligence gave him an unquestionable advantage over Madame le Gal and the Ministry of Foreign Affairs when it came to advising the president on the need for intervention (Jean-Louis Triaud in Mathias 2014: 13-14). The lack of an institutionally embedded alternative to the old Africa cell meant that it was the military that formulated and carried out French policy in Mali in 2013-2014 and that took the lead in establishing the follow-up Operation Barkhane. The Ministry of Foreign Affairs was sidelined at the moments when key decisions were taken.

Some commentators have, however, adopted a more sceptical attitude towards the notion of a new Africa strategy and have questioned whether the stated commitment to multilateralism and the new language of partnership are not simply a cover by means of which France has sought to relegitimize its military interventions on the continent (Granvaud 2014; Vallin 2015: 96). The old-style bilateral defence agreements and unilateral interventions had been seen as increasingly unacceptable since the 1990s, opening France to criticism at both the domestic and international level. The moves to 'Africanize' and 'Europeanize' policy were designed in large part to reduce the political risks of French military operations, but also to avoid the charge of neo-colonialism. More recently, the language of humanitarianism and partnership with Africa, together with the importance attached to gaining the prior approval of African regional and international organizations for any proposed military intervention, have served to defuse accusations of neocolonialism. Moreover, with the emergence of Africa as a key focus of international efforts to combat global terrorism, fighting alongside African allies to counter the spread of terrorism - as when France and Chad combined forces in Operation Serval and when France and the 'G5 Sahel' countries came together to form Operation Barkhane - has provided a new legitimacy for French 
military actions on the continent. As a result, France has become less afraid of criticism of its role as a 'neocolonial' actor in Africa, which has in turn facilitated the move back to more unilateral interventions. Moreover, related to this, Operation Barkhane raises new questions about the French commitment to 'Africanization'. France's Operation Serval and the deployment of Chadian troops had already marginalized ECOWAS (ICG 2016: 16); Operation Barkhane confirms this marginalization; it bypasses ECOWAS - neither Mauritania nor Chad is a member of the organization - and enables France to present itself as the key actor guaranteeing peace and security in the West African region.

\section{Conclusion}

The lack of a coherent strategy meant that France's Africa policy under President Hollande was initially driven above all by the need to react to events, but in the context of one overriding imperative: the idea that Africa has been since the colonial period, and remains to this day, the foundation stone of France's ambition to remain a global power. Outside Europe, it is the privileged arena for the projection of French power overseas. Having made it very clear that France would not intervene in either Mali or CAR, the sense of historical destiny, combined with the expectations of African leaders, the international community and the French military, meant that Hollande ultimately decided that France should intervene.

This decision has thrown light on some key particularities of, and developments in, France's Africa policy under President Hollande. First, the failure to reform the policy-making architecture for Africa policy in Paris - and in particular the fact that there has been no change to the role of the Ministry of Defence in Africa policy and there is still no institutionally embedded alternative to the 'Africa cell' at the Elysée Palace - played an important role in 
facilitating the decision to intervene. For as long as this remains the case, Africa policy will likely continue to be characterized by path dependency (Quénot-Suarez and Leboeuf 2014: 59) and a continuing gap between a discourse of reform and underlying continuities in policy. This has inevitably impacted on the French government's efforts to renew Africa policy.

Second, successive French governments had, since the late 1990s, promoted a policy of 'Europeanization' of Africa policy and 'Africanization' of responsibility for peace and security on the continent. In keeping with this policy, in the autumn of 2012 President Hollande stated that his government would not 'put boots on the ground' in Mali. However, by January 2013, the French military had lost interest in the policy of 'Europeanization', become frustrated by the reluctance of the UN Security Council to act, by ECOWAS's lack of capacity and by the inconclusiveness of ECOWAS meetings (ICG 2016: 16; Marchal 2013: 488). In the end, Hollande was persuaded that the maintenance of France's great power status meant assuming its responsibility as a global power. A 'partner country' in the pre-carré had asked for support, the UNSC was supportive and regional heads of government had asked France for help; it was therefore France's responsibility to intervene.

Third, the decision to intervene drew attention to the fundamental contradiction between the continuing importance attached by France's governing elites to Africa as the key arena for the projection of French power overseas and the discourse of multilateralism and partnership. In the military sphere, there has since 2012 been increased emphasis, notably in the 2013 white paper, on French autonomy of decision-making and action. This raises questions about the depth of the real French commitment to multilateralism and partnership. Furthermore, multilateralism can work as an element of a strategy, but only if others are prepared to play their part. As one official of the UN Department of Peacekeeping Operations put it: 'Because everyone seems to 
expect that the French state will eventually intervene, volunteers and alternative conflict resolution strategies are left wanting' (Interview, UN Secretariat, New York, 9 December 2013, quoted by Charbonneau and Sears 2014: 199). Clearly, for as long as France has pre-positioned forces on the ground in Africa and is willing to deploy them, others are happy to let France bear the costs and risks of intervention.

Fourth, in terms of legitimizing its military role in Africa, France has in recent years changed its strategy. Following widespread domestic and international criticism of its role in Rwanda, in the late 1990s France initially appeared to abandon unilateral military actions that ran the risk that France would be accused of being a neo-colonial power, the 'gendarme' of Africa. The 'Europeanization' and 'Africanization' of policy were the twin pillars of a new African policy that was supposed to provide the means to avoid such criticisms in future. However, the fight against terrorism has provided a new legitimacy for French military actions on the continent, with the result that, under the Hollande presidency France has apparently become less afraid of criticism of its role as a 'neocolonial' actor in Africa, which has in turn facilitated the move back to more unilateral interventions. The discourse of partnership remains, but the reality is that the EU and African actors have essentially been reduced to supporting roles. France's new Africa policy thus remains some distance from representing a genuinely new, more equal partnership with Africa.

Finally, there are important questions over the long-term viability of the government's Africa policy. As Roland Marchal (2014) has pointed out, there are political costs to allying France closely with an authoritarian regime (Chad) with a poor human rights record. The issue is, in the first instance, one of coherence between a discourse of humanitarianism and democracy and a political and military practice that belies that discourse. More importantly however, this 
policy has long-term security implications. In the 1980s, western states supported dictatorships in many Arab states in the Middle East and North Africa in order to counter political Islam. The outcome was not only the terrorist attacks of 11 September 2001, but the inability of the leaders of these states to offer an alternative to Islamist fundamentalism. The western discourse on democratic values and human rights was trumped by security concerns and lost credibility. This has been a long-standing contradiction as far as French relations with Africa are concerned and it is one that Operation Barkhane perpetuates. Moreover, with some 10,000 troops now stationed in Africa and Operation Barkhane spanning five countries, the cost of its military presence and actions on the continent is high. In 2015 President Hollande announced an increase in the defence budget, but sustaining all of France's military commitments in the current difficult economic context will remain challenging.

\section{Acknowledgements}

The author wishes to thank Bruno Charbonneau, Margaret Majumdar and Elisa Lopez Lucia for their very helpful comments on an earlier draft of this article.

\section{References}

Ambassade de France à Tunis (2013), 'Conférence de presse de M. Laurent Fabius', Press conference, 14 janvier, http://www.ambassadefrance-tn.org/Engagement-de-la-France-au-Mali. Accessed 28 February 2015. 
Assemblée Nationale (2013), 'Audition de l'amiral Édouard Guillaud sur les enseignements de l'opération Serval', Commission de la défense nationale et des forces armées, Compte rendu 74, 22 May, http://www.assemblee-nationale.fr/14/cr-cdef/12-13/c1213074.asp\#P7_246. Accessed 2 March 2015.

(2014), 'Rapport d'information sur l'opération Serval au Mali', http://www.assembleenationale.fr/14/rap-info/i1288.asp\#P1309_194320. Accessed 20 February 2015.

BBC (2014), 'France sets up anti-Islamist force in Africa's Sahel', http://www.bbc.co.uk/news/world-europe-28298230. Accessed 14 June 2016.

Bergamaschi, I. (2014), 'The fall of a donor darling: The role of aid in Mali's crisis', Journal of Modern African Studies, 52:3, pp. 347-78.

Bergamaschi, I. and Diawara, M. (2014), 'The French military intervention in Mali: Not exactly Françafrique but definitely post-colonial', in B. Charbonneau and T. Chafer (eds), Peace Operations in the Francophone World, London: Routledge, pp. 137-52.

Boeke, S. and Tisseron, A. (2014), 'Mali's long road ahead', RUSI Journal, 159:5, pp. 32-40.

Bouverie, J. (2013), 'Mali's premature elections threaten stability and future legitimacy', ThinkAfricaPress, 28 May, http://thinkafricapress.com/mali/premature-election-threatenspeace-and-stability. Accessed 15 March 2015. 
Chafer, T. (2002), 'Franco-African relations: No longer so exceptional?', African Affairs, 101:404, pp. 343-63.

(2014), 'Hollande and Africa policy', Modern and Contemporary France, 22:4, pp. 51331.

Charbonneau, B. (2014), 'The imperial legacy of international peacebuilding: The case of francophone Africa', Review of International Studies, 40:3, pp. 607-30.

Charbonneau, B. and Chafer, T. (eds) (2014), Peace Operations in the Francophone World, London: Routledge.

Charbonneau, B. and Sears, J. (2014), 'Fighting for liberal peace in Mali? The limits of international military intervention', Journal of Intervention and Statebuilding, 8:2-3, pp. 192213.

Chivvis, C. (2016), The French War on Al Qa'ida in Africa, New York: Cambridge University Press.

European External Action Service (2011), 'Strategy for security and development in the Sahel', European External Action $\quad$ Service, $\quad$ Brussels, http://eeas.europa.eu/africa/docs/sahel_strategy_en.pdf. Accessed 28 February 2013. 
France at the United Nations (2014), 'Central African Republic', http://www.franceonu.org/france-at-the-united-nations/geographic-files/africa/central-africanrepublic/article/central-african-republic. Accessed 27 February 2015.

Glaser, A. (2014), AfricaFrance: Quand les dirigeants africains deviennent les maîtres du jeu, Paris: Fayard.

Granvaud, R. (2014), 'La France réorganise ses troupes en Afrique', Billets d'Afrique, no. 238, September, p. 4-5.

Harmon, S. (2015), 'Securitization initiatives in the Sahara-Sahel region in the twenty-first century', African Security, 8:4, pp. 227-48.

Hollande, F. (2013a), 'Discours lors de la rencontre avec les personnels français des forces présentes au Mali', http://www.elysee.fr/declarations/article/discours-lors-de-la-rencontre-avecles-personnels-francais-des-forces-presentes-au-mali/. Accessed 28 February 2015.

(2013b), 'Discours du Président de la République et de M. Dioncounda Traoré, Président de la République du Mali, depuis la place de l'indépendance à Bamako, Mali', http://www.elysee.fr/videos/discours-avec-le-president-de-la-republique-du-mali-depuis-laplace-de-1-039-independance-a-bamako-mali/. Accessed 29 February 2016. 
International Crisis Group [ICG] (2012), 'Mali: the need for determined and coordinated international action', Africa Briefing, no. 90, International Crisis Group, Dakar and Brussels.

(2016), 'Implementing peace and Security architecture (III): West Africa', Africa Report, no. 234, International Crisis Group, Brussels.

Institute for Security Studies (2013), 'Zuma suppresses his suspicions about France to collaborate on solving the CAR crisis', Institute for Security Studies, 17 October, http://www.issafrica.org/iss-today/zuma-suppresses-his-suspicions-about-france-to-collaborateon-solving-the-car-crisis. Accessed 20 March 2015.

Jauvert, V. and Halifa-Legrand, S. (2013), 'Mali: Histoire secrète d'une guerre surprise', Nouvel Observateur, 7 February.

Livre Blanc (2008), Livre Blanc: Défense et sécurité nationale, Paris: Ministry of Defence. (2013), Livre Blanc: Défense et sécurité nationale, Paris: Ministry of Defence.

Marchal, R. (2012), 'Is a military intervention in Mali unavoidable?', Oslo: Norwegian Peacebuilding Resource Centre (NOREF) Report, 22 October.

(2013), 'Briefing: Military (mis)adventures in Mali', African Affairs, 112:448, pp. 486-97. 
(2014), 'French military adventures in Africa', The Diplomatist, October, http://www.diplomatist.com/dipom10y2014/article015.html. Accessed 1 March 2015.

Mathias, G. (2014), Les Guerres africaines de François Hollande, La Tour d'Aigues: Eds de l'Aube.

Mélonio, T. (2011), Quelle politique africaine pour la France en 2012?, Paris: Fondation Jean Jaurès.

Ministère de la Défense (2013), 'Serval: Situation update', Thursday, 19 September, http://www.defense.gouv.fr/english/content/view/full/217762. Accessed 19 February 2015.

Newman, D. (2007), 'Geopolitics renaissant: Territory, sovereignty and the world political map', Geopolitics, 3:1, pp. 1-16.

Olsen, G. R. (2014), 'Fighting terrorism in Africa by proxy: The USA and the European Union in Somalia and Mali', European Security, 23:3, pp. 290-306.

Quénot-Suarez, H. and Leboeuf, A. (2014), La Politique africaine de la France sous François Hollande, Paris: Institut Français des Relations Internationales.

Richmond, O. P. (2011), A Post-Liberal Peace, London: Routledge. 
Sarkozy, N. (2006), 'Déclaration de M. Nicolas Sarkozy, ministre de l'intérieur et de l'aménagement du territoire, sur la démocratie au Bénin et sur l'établissement de nouvelles relations entre la France et l'Afrique', Cotonou, 19 mai, http://discours.viepublique.fr/notices/063001811.html. Accessed 16 March 2015.

(2007), 'Le discours de Nicolas Sarkozy à Dakar, le 26 juillet', http://ldh-toulon.net/lediscours-de-Nicolas-Sarkozy-a.html. Accessed 16 March 2015.

Smith, S. (2013), 'In search of monsters', London Review of Books, 35:3, pp. 3-5.

Styan, D. (2013), 'Chad's political violence at 50: Bullets, ballots and bases', in T. Chafer and A. Keese (eds), Francophone Africa at Fifty, Manchester: Manchester University Press, pp. 23348.

United Nations (2013), 'MINUSMA: United Nations stabilization mission in Mali', http://www.un.org/en/peacekeeping/missions/minusma/background.shtml. $\quad$ Accessed 19 February 2015.

Utley, R. (2005), 'Franco-Africa military relations: Meeting the challenges of globalisation?', Modern and Contemporary France, 13:1, pp. 25-40. 
Van de Walle, N. (2012), 'Foreign aid in dangerous places: The donors and Mali's democracy', UNU-WIDER Working Paper, no. 61, July, http://www.wider.unu.edu/publications/workingpapers/2012/en_GB/wp2012-061/. Accessed 15 March 2013.

\section{Contributor details}

Tony Chafer is Professor of French and African Studies at the University of Portsmouth (UK). He is a historian specializing on francophone Africa and French relations with Africa in the late colonial and postcolonial periods. His monograph on decolonization in French West Africa, The End of Empire in French West Africa: France's Successful Decolonization? was published in 2002. A translation into French is forthcoming. Recently, he has published a number of articles on French Africa policy, including 'French African policy in historical perspective', in T. Young (ed.), Readings in the International Relations of Africa (2016); Françafrique - the state of relations between France and Africa, Europa Regional (45, 2016); 'Partir pour mieux rester: le cas du Sénégal', in B. Salvaing (ed.) Pouvoirs anciens, pouvoirs modernes dans l'Afrique d'aujourd'hui (2015); and 'Hollande and Africa policy', Modern and Contemporary France (22:4, 2014). Recent edited works include Peace Operations in the Francophone World: Global Governance meets Post-Colonialism (2014) (with Bruno Charbonneau) and Francophone Africa at Fifty (with Alexander Keese) (2013). He has also published articles in African Affairs, The

Journal of Modern African Studies, Afrique Contemporaine and the Journal of Imperial and Commonwealth History.

Contact: 
Centre for European \& International Studies Research, Park Building, King Henry I Street, Portsmouth PO1 2DZ, UK.

E-mail: tony.chafer@port.ac.uk

Notes

${ }^{1}$ The term Françafrique was originally coined in 1963 by former president of Côte d'Ivoire Félix Houphouët-Boigny to describe the common destiny and promote the special relationship between France and Africa that he supported and wanted to maintain. At the time it was not considered in any way pejorative. The term was later adopted by François-Xavier Verschave (1998) to denounce the shady, often corrupt practices that have often characterized Franco-African relations in the postcolonial period.

${ }^{2}$ The focus here is on military policy. I have dealt with the economic dimension of French Africa policy in another article, see Chafer (2014).

${ }^{3}$ Richmond (2011: 1) defines the liberal peace as 'a model through which Western led agency, epistemology, and institutions, have attempted to unite the world under a hegemonic system that replicates liberal institutions, norms, and political, social, and economic systems'. 